\title{
UPAYA MENINGKATKAN HASIL BELAJAR SISWA PADA MATA PELAJARAN MENGGAMBAR TEKNIK MELALUI MODEL PEMBELAJARAN KOOPERATIF TIPE TEAM QUIZ PADA SISWA KELAS X PROGRAM KEAHLIAN TEKNIK MESIN PRODUKSI SMK NEGERI 2 TANJUNGBALAI T.A 2016/2017
}

\author{
Mariaman Situmorang dan Lisyanto \\ (Tutor Bimbel Medika dan Dosen Pendidikan Teknik Mesin)
}

\begin{abstract}
ABSTRAK
Penelitian ini merupakan penelitian tindakan kelas yang bertujuan untuk meningkatkan hasil belajar Menggambar Teknik mata pelajaran Menggambar Teknik siswa kelas X Teknik Mesin Produksi di SMK Negeri 2 Tanjungbalai tahun ajaran 2016/2017. Menggambar Teknik merupakan salah satu program mata diklat pada pendidikan kejuruan program studi keahlian Teknik Mesin Produksi. Melalui tindakan berupa penerapan model pembelajaran kooperatif tipe Team Quiz, diharapkan dapat meningkatkan hasil belajar Menggambar Teknik pada siswa kelas $\mathrm{X}$ Teknik Mesin Produksi. Metode penelitian yang digunakan adalah penelitian tindakan kelas model Arikunto yang dilaksanakan dalam 2 siklus, dimana dalam setiap 1 siklus dilaksanakan dalam 1 pertemuan dan pada setiap siklus diselesaikan melalui tahap perencanan, tahap pelaksanaan tindakan, tahap pengamatan, dan tahap refleksi. Subjek pada penelitian ini adalah siswa kelas X TP SMK Negeri 2 Tanjungbalai terdiri dari 30 orang. Pengumpulan data yang digunakan dalam penelitian ini adalah pilihan berganda dan Esay. Hasil penelitian menunjukkan bahwa penerapan model pembelajaran kooperatif tipe Team Quiz dapat meningkatkan hasil belajar Menggambar teknik mata pelajaran Menggambar Teknik pada siswa kelas X Teknik Mesin Produksi di SMK Negeri 2 Tanjungbalai. Hal tersebut dapat dilihat dari pencapaian persentase ketuntasan belajar secara klasikal yakni $40 \%$ pada siklus I dan $86,67 \%$ pada siklus II, serta pencapaian nilai rata-rata kelas sebesar 61,17 pada siklus I dan 82 pada siklus II.
\end{abstract}

\section{Kata kunci: Model Pembelajaran Kooperatif Tipe Team Quiz, Hasil Belajar Siswa,} Menggambar Teknik.

\section{PENDAHULUAN}

Seiring dengan perkembangan ilmu pengetahuan dan teknologi yang semakin pesat, menuntut manusia untuk terus mengembangkan wawasan dan kemampuan di berbagai bidang. Oleh karena itu pendidikan harus dilaksanakan dengan sebaik mungkin sehingga akan memperoleh hasil yang diharapkan.

Undang-Undang Nomor 20 Tahun 2003 tentang Sistem Pendidikan Nasional menyatakan bahwa pendidikan adalah usaha sadar dan terencana untuk mewujudkan suasana belajar dan proses pembelajaran agar siswa aktif mengembangkan potensi diri untuk memiliki kekuatan spiritual keagamaan, pengendalian diri, kepribadian, kecerdasan, akhlak mulia, serta keterampilan yang diperlukan dirinya, masyarakat, bangsa dan negara.

\begin{abstract}
Kualitas suatu bangsa sangat ditentukan oleh faktor pendidikan. Peran pendidikan sangat penting untuk menciptakan kehidupan yang cerdas, damai, terbuka dan demokratis. Upaya peningkatan mutu pendidikan dilakukan dengan harapan dapat menaikkan harkat dan martabat manusia Indonesia. Untuk mencapai itu, pendidikan harus adaptif terhadap perubahan zaman.
\end{abstract}

Sekolah Menengah Kejuruan (SMK) sebagai institusi pendidikan nasional memiliki peranan yang sangat penting dalam mencerdaskan dan meningkatkan kualitas SDM yang memiliki kompetensi dalam bidang keteknikan. SMK sebagai salah satu sekolah kejuruan terus berusaha dan semakin ditantang untuk meningkatkan hasil lulusan yang benar-benar mempunyai skill atau kemampuan dalam bidangnya masingmasing. Untuk mencapai hal tersebut maka 
dibutuhkan pembelajaran yang tepat dan efektif untuk siswa SMK yang sesuai dengan kurikulum dan mengaitkan materi yang diajarkan guru dengan penerapan yang tepat dalam kehidupan masyarakat umumnya dan masyarakat sekitar siswa khususnya.

Hal ini sesuai dengan tujuan SMK dalam GBPP, yaitu : (1) Menyiapkan siswa untuk memasuki lapangan kerja serta mengembangkan sikap profesional, (2) Menyiapkan siswa agar mampu memilih karir, mampu berkompetensi dan mampu mengembangkan diri, (3) Menyiapkan tenaga kerja tingkat menengah pada saat ini maupun pada saat mendatang, (4) Menyiapkan tamatan agar mampu menjadi warga negara yang produktif, adaptif dan kreatif. Tujuan pembelajaran Menggambar teknik, yaitu : (1) Siswa mengetahui pengertian gambar teknik dan tujuan belajar gambar teknik, (2) Siswa mengetahui alat-alat menggambar teknik dan skala-skala gambar teknik, (3) Siswa mampu menggambar teknik dan membaca gambar teknik.

Untuk mengetahui keadaan yang sebenarnya disekolah tentang penyebab rendahnya hasil belajar siswa, maka penulis melakukan observasi ke SMK Negeri 2 Tanjung Balai untuk program studi Teknik Pemesinan khususnya pada mata pelajaran Menggambar Teknik pada bulan Desember 2014. Observasi di SMK Negeri 2 Tanjung Balai menunjukkan hasil belajar Menggambar Teknik siswa masih berada dibawah standar rata-rata yang ditetapkan oleh Depdiknas untuk mata diklat produktif yaitu 7,50 dan nilai rata-rata yang diperoleh siswa berdasarkan data dari Daftar Kumpulan Nilai (DKN) siswa tingkat I untuk standar kompetensi Menggambar Teknik pada Tahun Ajaran 2014/2015 sebesar 71,37. Dari wawancara dengan guru mata pelajaran Menggambar Teknik khususnya pada materi Menggambar Teknik, sebagian hasil belajar siswa kurang memenuhi standart rata-rata sehingga untuk mencapai standart tersebut siswa akan mengikuti ujian remedial. Ujian remedial dilakukan untuk siswa yang hasil belajarnya dibawah standart kompetensi $(7,50)$. Pelaksanaan ujian remedial tidak begitu jauh dari pelaksanan ujian kompetensi. dipandang penulis dapat meningkatkan keinginan belajar siswa dan dapat mengatasi kesulitan belajar khususnya materi pelajaran teori, tanpa melupakan strategi pembelajaran lainnya untuk meningkatkan hasil belajar Menggambar Teknik pada siswa adalah strategi pembelajaran Kooperatif (Tipe Team Quis). Pembelajaran Kooperatif (Tipe Team Quis) merupakan aktivitas pembelajaran kelompok yang diorganisir oleh satu prinsip bahwa pembelajaran harus didasarkan pada perubahan informasi secara sosial diantara kelompok-kelompok pembelajar yang didalamnya setiap pembelajar bertangngung jawab atas pembelajarannya sendiri dan didorong untuk meningkatkan pembelajaran anggota-anggota yang lain

Dalam pembelajaran kenyataannya sebagian siswa tidak mampu menghubungkan antara apa yang mereka pelajari dengan bagaimana pemanfaatannya dalam kehidupan nyata. Hal ini karena pemahaman konsep akademik yang diperoleh hanyalah merupakan sesuatu yang abstrak, belum menyentuh kebutuhan praktis kehidupan baik dilingkungan kerja maupun di masyarakat. Pembelajaran yang selama ini diterima hanyalah penonjolan tingkat hafalan dari sekian pokok bahasan, tetapi tidak diikuti dengan pemahaman atau pengertian yang mendalam yang bisa diterapkan dalam kehidupannya.

Satu dari beberapa model pembelajaran yang dipandang penulis dapat mengatasi masalah ini serta untuk meningkatkan hasil belajar menggambar teknik ini adalah dengan menggunakan Model Pembelajaran Kooperatif Tipe Team Qiuz. Model ini digunakan karena dapat meningkatkan tanggung jawab belajar peserta didik dalam suasana yang menyenangkan.

\section{KAJIAN TEORI \\ 1. Pengertian Belajar}

Sebagai pelajar, belajar menjadi gaya hidup kita. Kita sadari atau tidak setiap hari kita sering terlibat dalam belajar atau bahkan kita lakukan dengan sengaja sesuai dengan keinginan kita, bahkan merupakan bagian 
yang tidak terpisahakan dari diri pelajar dalam menuntut ilmu di lembaga pendidikan formal.

\section{Pengertian Pembelajaran}

Istilah pembelajaran berhubungan erat dengan pengertian belajar dan mengajar. Pembelajaran adalah proses, cara menjadikan orang atau makhluk hidup belajar. Dalam Undang-Undang No. 23 Tahun 2003 Tentang SISDIKNAS Pembelajaran diartikan sebagai proses interaksi peserta didik dengan pendidik dan sumber belajar pada suatu lingkungan belajar.

\section{Pengertian Model}

Menurut pendapat Mills yang dikutip oleh Agus Suprijono (2009) model adalah bentuk representase akurat sebagai proses aktual yang memungkinkan seseorang atau sekelompok orang mencoba bertindak berdasarkan model itu.

\section{Pengertian Model Pembelajaran}

Merujuk dari beberapa pengertian tentang model, belajar dan pembelajaran sesuai kajian teori di atas, dapat ditarik kesimpulan bahwa model pembelajaran yaitu suatu pola yang digunakan sebagai pedoman dalam mempengaruhi tingkah laku seseorang atau sekelompok orang.

\section{Pengertian Hasil Belajar}

Berdasarkan pengertian di atas dapat disimpulkan bahwa hasil belajar adalah sesuatau yang dicapai atau diperoleh setelah adanya proses belajar mengajar. Dan yang diperoleh berupa perubahan dari segi kognitif, afektif dan psikomotor setelah mempelajari suatu materi baik secara kuantitatif maupun kualitatif. Dan adanya peningkatan kemampuan yang diperoleh siswa tentang materi pelajaran tertentu yang dipelajarinya yang dapat diukur dalam bentuk nilai-nilai.

\section{Jenis-Jenis Model Pembelajaran}

Ada banyak model-model pembelajaran yang disusun berdasarkan prinsip atau teori sebagai pijakan dalam pengembangannya. Dalam bukunya, Rusman (2012) menyajikan beberapa model-model pembelajaran diantaranya : 1) Model pembelajaran kontekstual; 2) Model pembelajaran berbasis masalah; 3) Model pembelajaran tematik; 4) Model pembelajaran berbasis computer; 5) Model
PAKEM ( Partisipatif, Aktif, Kreatif, Efektif, dan Menyenangkan); 6) Model pembelajaran berbasis web; 7) Model pembelajaran mandiri dan masih banyak yang lainnya termasuk Model Pembelajaran Kooperatif.

\section{Pembelajaran Kooperatif}

Pembelajaran kooperatif ini dikembangankan dari teori konstruktivisme yang lahir dari gagasan Piaget dan Vygotsky (2011) dikemukakan bahwa pengetahuan itu dibangun dalam pikiran anak. Vygotsky (2011) menekankan peserta didik mengonstruksi pengetahuan melalui interaksi sosial dengan orang lain. Menurut pandangan Piaget dan Vigostky adanya hakikat sosial dari sebuah proses belajar akan melahirkan interaksi dengan sesama melalui pembentukan kelompok belajar.

\section{Pembelajaran Kooperatif Tipe Team Quiz}

Menurut Sugiyanto (2009: 58) yang dikutip oleh Elizabeth Septi Prasetyaningish dkk model pembelajaran kooperatif tipe Team Quiz adalah model pembelajaran dengan memainkan topik-topik yang diajarkan kepada siswa yang dibagi dalam beberapa kelompok-kelompok besar.

\section{METODOLOGI PENELITIAN}

Penelitian ini akan dilaksanakan di SMK Negeri 2 Tanjungbalai Kota Tanjungbalai, yang dilaksanakan pada bulan Agustus 2016. Subjek penelitian ini adalah siswa kelas X SMK N. 2 Tanjungbalai Kota Tanjungbalai Tahun Pelajaran 2016/2017 yaitu sebanyak 1 kelas dengan jumlah 30 orang.

Objek dalam penelitian ini adalah hasil belajar siswa dengan model pembelajaran kooperatif tipe Team Quiz pada materi Pelajaran Menggambar Teknik di kelas X SMK Negeri 2 Tanjungbalai Kota Tanjungbalai T.A 2016/2017.

Jenis penelitian ini adalah Penelitian Tindakan Kelas dengan menggunakan strategi pembelajaran kooperatif tipe Team Quiz sebagai sasaran utama. Penelitian ini berusaha memaparkan upaya meningkatkan hasil belajar siswa pada mata pelajaran 
Menggambar Teknik melalui model pembelajaran Kooperatif Tipe Team Quiz.

Prosedur pelaksanaan penelitian tindakan kelas ini memiliki alur sebagaimana gambar dibawah ini menurut Suharsimi, Arikunto (2009:16), dapat digambarkan sebagai berikut:

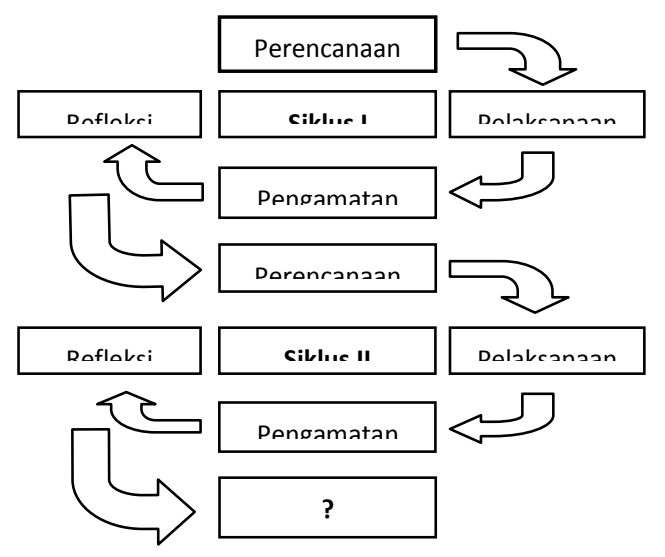

Gambar Model Penelitian Tindakan Kelas

Analisis data adalah proses mencari dan menyusun secara sistematis data yang diperoleh dari hasil wawancara, catatan lapangan dan dokumentasi dengan cara mengorganisasikan data ke dalam kategori, menjabarkan ke dalam unit-unit, melakukan sintesa, menyusun ke dalam pola, memilih mana yang penting dan yang akan dipelajari, dan membuat kesimpulan sehingga mudah dipahami oleh diri sendiri maupun orang lain. teknik analisis data dilakukan dengan melalui tiga tahap, yaitu mereduksi data, pemaparan data, dan penyimpulan.

Untuk mengetahui tingkat penguasaan siswa terhadap materi yang telah diajarkan dalam kegiatan pembelajaran, Nurkencana (1980:80) menjelaskan bahwa : "Tingkat penguasaan siswa akan tercermin pada tinggi rendahnya skor mentah yang dicapai dan pedoman konversi yang umum digunakan adalah dalam skala lima normal absolute (suatu pembagian tingkat)".
Tabel Pedoman Skala Lima Normal Absolute

\begin{tabular}{|c|c|}
\hline Tingkat Penguasaan & Kategori \\
\hline $90 \%-100 \%$ & Sangat Tinggi (A) \\
$80 \%-89 \%$ & Tinggi (B) \\
$65 \%-79 \%$ & Sedang (C) \\
$55 \%-64 \%$ & Rendah (D) \\
$0 \%-54 \%$ & Sangat Rendah (E) \\
\hline
\end{tabular}

Sumber: Nurkencana (1980:80)

Berdasarkan pedoman skala lima normal absolute pada tabel.6 diatas maka kriteria ketercapaian tingkat penguasaan siswa adalah apabila paling sedikit skor siswa mencapai kategori sedang. Tingkat penguasaan kemampuan pemahaman Gambar teknik siswa dengan cara melihat persentase tiap skor total yang diperoleh siswa dan dihitung dengan menggunakan rumus :

Tingkat penguasaan $=\frac{\text { jumlahskortotal subjek }}{\text { jumlah skortotal maksimal }} \times 100 \%$

Untuk menghitung hasil belajar Menggambar Teknik siswa pada materi gambar teknik telah meningkat atau tidak, dapat dilihat dari hasil tes yang mereka peroleh setiap siklusnya. Dimana setiap skor masing-masing tes yang diberikan akan dilihat ketuntasannya baik secara perorangan, maupun secara klasikal dengan menggunakan persamaan seperti yang diungkapkan oleh Trianto (2009:241), bahwa:

$$
K B=\frac{T}{T_{t}} x 100 \%
$$

Keterangan:

$\mathrm{KB}=$ Ketuntasan Belajar

$\mathrm{T}=$ Jumlah Skor yang Diperoleh Siswa

$\mathrm{T}_{\mathrm{t}}=$ Jumlah Skor Total

Dengan kriteria:

$0 \% \leq \mathrm{KB}<70 \%$ belum tuntas

$70 \% \leq \mathrm{KB} \leq 100 \%$ tuntas 
Kemudian dapat juga diketahui apakah ketuntasaan belajar siswa secara klasikal telah tercapai, hal ini dilihat dari persentase siswa yang telah tuntas dalam belajar yang dirumuskan seperti dibawah ini :

PKK $=\frac{\text { banyak siswayangketuntasan belajarnya } \geq 70 \%}{\text { banyak subjek penelitian }} \times 100 \%$

Keterangan :

PKK = Presentase Ketuntasan Klasikal

1) Seorang siswa dikatakan telah tuntas belajar jika siswa tersebut telah mencapai skor paling sedikitnya 75 dari total skor.

2) Suatu kelas dikatakan telah tuntas belajar jika dalam kelas tersebut mencapai skor paling sedikitnya $85 \%$ dari jumlah siswa seluruhnya telah mencapai skor 75 .

\section{HASIL DAN PEMBAHASAN}

\section{Hasil Penelitian}

Penelitian ini dilaksanakan di SMK Negeri 2 Tanjungbalai kota Tanjung balai dengan menerapkan model pembelajaran kooperatif tipe Team Quiz untuk meningkatkan hasil belajar Menggambar Teknik mata pelajaran Gambar Teknik Mesin pada siswa kelas $\mathrm{X}$ TP tahun ajaran 2016/2017. Penelitian ini merupakan Penelitian Tindakan Kelas yang dilaksanakan bersiklus dimana masingmasing siklus diselesaikan dengan 2 kali pertemuan melalui empat tahapan, yaitu: 1) Tahap perencanaan, 2) Tahap pelaksanaan, 3) Tahap pengamatan atau observasi dan 4) Tahap refleksi.

Dari hasil belajar siswa yang diperoleh pada akhir Siklus I selesai maka diketahui nilai hasil belajar siswa dengan kategori kurang sebanyak 18 orang (60\%), cukup sebanyak 10 orang $(33,33 \%)$, dan baik sebanyak 2 orang $(6,67 \%)$. Berdasarkan data di atas nilai perolehan rata-rata 61,17 .

\section{Analisis Peningkatan Pembelajaran Siklus I dan Siklus II}

Berdasarkan data hasil belajar yang diperoleh dari hasil penelitian, dapat dianalisis perbandingan hasil belajar untuk setiap siklusnya, seperti yang dirincikan pada Tabel berikut:

Tabel Data Hasil Belajar Posttest pada Siklus I dan Siklus II

\begin{tabular}{|c|c|c|c|c|}
\hline \multirow{4}{*}{$\begin{array}{c}\text { Kategori } \\
\text { Penilaian }\end{array}$} & \multicolumn{2}{|c|}{$\begin{array}{c}\text { Hasil } \\
\text { Belajar } \\
\text { Siklus I }\end{array}$} & \multicolumn{2}{|c|}{$\begin{array}{c}\text { Hasil } \\
\text { Belajar } \\
\text { Siklus II }\end{array}$} \\
\cline { 2 - 5 } & \multicolumn{2}{|c|}{ Posttest } & \multicolumn{2}{|c|}{ Posttest } \\
\cline { 2 - 5 } & $\begin{array}{c}\text { Jumlah } \\
\text { Siswa }\end{array}$ & $\begin{array}{c}\text { Jumlah } \\
\text { Siswa }\end{array}$ & $(\%)$ \\
\hline Tidak Tuntas & 18 & 60 & 26 & 13,33 \\
\hline Tuntas & 12 & 40 & 4 & 86,67 \\
\hline
\end{tabular}

Berdasarkan Tabel, dapat dilihat peningkatan hasil belajar siswa dengan penerapan model pembelajaran kooperatif tipe Team Quiz. Berikut diagram histogram perolehan hasil belajar posttest pada siklus I dan siklus II:

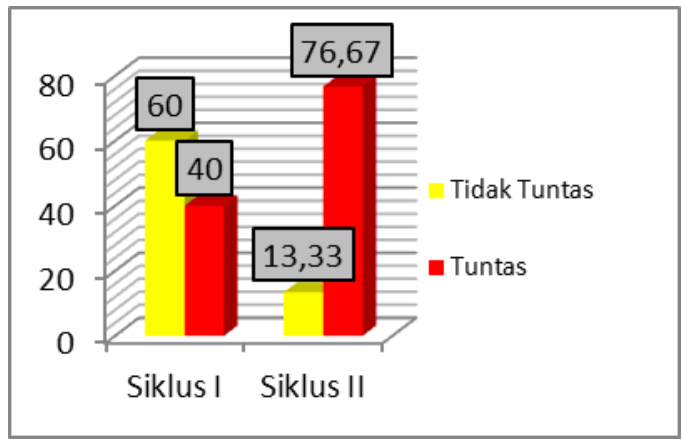

\section{Gambar Persentase Hasil Belajar Posttest pada Siklus I dan Siklus II}

Nilai rata-rata hasil belajar pada siklus I adalah 61,17, sedangkan nilai rata-rata pada Siklus II adalah 82. Selisih nilai rata-rata hasil belajar dari siklus I ke siklus II adalah sebesar 20,83. Persentase peningkatan hasil belajar siswa dapat dihitung dengan rumus sebagai berikut :

Peningkatan Hasil Belajar $=\frac{P-Q}{Q} \times 100$

Dimana:

$\mathrm{P}=$ Rata-rata nilai siklus II

$\mathrm{Q}=$ Rata-rata nilai siklus I

Maka: 
Peningkatan Hasil Belajar $=\frac{82-51,17}{61,18} \times 100=34,05 \%$

Berdasarkan rumus di atas, maka diperoleh persentase rata-rata peningkatan hasil belajar siswa secara klasikal dari hasil posttest siklus I ke siklus II adalah sebesar $34,05 \%$.

\section{Pembahasan Penelitian}

Dari hasil analisis data penelitan, untuk siklus I diperoleh data sebagai berikut: a) Nilai rata-rata hasil belajar siswa adalah 61,17; b) Persentase ketuntasan hasil belajar siswa secara klasikal adalah sebesar $40 \%$. Untuk siklus II diperoleh data sebagai berikut: a) Nilai rata-rata hasil belajar siswa adalah 82 ; b) Persentase ketuntasan hasil belajar siswa secara klasikal adalah sebesar $86,67 \%$. Peningkatan nilai rata-rata hasil belajar siswa dari siklus I ke siklus II adalah 20,83; dan persentase rata-rata peningkatan hasil belajar siswa secara klasikal dari hasil posttest siklus I ke siklus II adalah sebesar $34,05 \%$.

Penerapan model pembelajaran kooperatif tipe Team Quiz bertujuan untuk meningkatkan hasil belajar Menggambar Teknik pada siswa kelas X Teknik Mesin di SMK Negeri 2 Tanjungbalai, berdasarkan hasil analisis data di atas tujuan penelitian ini telah terpenuhi berdasarkan indikator keberhasilan penelitian. Berdasarkan hasil penelitian penerapan model pembelajaran dapat meningkatkan hasil belajar siswa.

Pelaksanaan penelitian ini telah dilaksanakan dengan sebaik mungkin dengan menggunakan prosedur metode ilmiah, akan tetapi apapun metode yang digunakan tidak tertutup kemungkinan ada kekeliruan dan kesalahan, sebab pelaksana dalam penelitian ini adalah manusia, yang diteliti juga manusia yang tidak terlepas dari kesalahan dan kelemahan. Maka dalam penelitian ini perlu diungkapkan keterbatasan penelitian. Data variable hasil belajar siswa diperoleh dengan menggunakan tes pilihan berganda yang diberikan terhadap responden terpilih.
Pengukuran dengan tes pilihan berganda mempunyai keterbatasan seperti yang dikemukakan oleh Arikunto (2006 :16) : (a) persiapan untuk menyusun tes jauh lebih sulit, (b) banyak kesempatan untuk main tebak-tebakan dan (c) kerja sama antar siswa pada waktu pengerjaan soal-soal lebih terbuka. Dalam hal ini menyebabkan adanya kemungkinan bahwa siswa telah bekerja sama untuk memberikan jawaban. Untuk mengatasi masalah tersebut dihimbau kepada siswa untuk mengutamakan kejujuran dalam memberikan jawaban sesuai dengan kemampuannya saja.

Dengan demikian hipotesis dalam penelitian yang berbunyi Penerapan model pembelajaran kooperatif tipe Team Quiz dapat meningkatan hasil belajar siswa kelas $X$ TP semester ganjil di SMK Negeri 2 Tanjungbalai pada pelajaran Menggambar Teknik. Teruji kebenarannya, atau dengan kata lain hipotesis diterima..

\section{KESIMPULAN}

Berdasarkan hasil dan pembahasan penelitian, maka kesimpulan dalam penelitian ini adalah: "Penerapan model pembelajaran kooperatif tipe Team Quiz dapat meningkatkan hasil belajar Menggambar Teknik pada siswa kelas X Teknik Mesin di SMK Negeri 2 Tanjungbalai tahun ajaran 2016/2017". Peningkatan hasil belajar siswa tersebut yakni : a) Pada siklus I ketuntasan belajar siswa secara klasikal sebanyak 12 orang dengan persentase sebesar $40 \%$ dengan nilai rata-rata kelas 61,17 ; b) Pada siklus II ketuntasan belajar siswa secara klasikal sebanyak 26 orang dengan persentase sebesar $86,67 \%$ dengan nilai ratarata kelas 82 .

\section{DAFTAR PUSTAKA}

Alfred Hendra Girsang. (2011). Pembelajaran Aktif Tipe Quiz Team Terhadap Hasil Belajar Pada Standar Kompetensi Pada Siswa Tingkat Dua Program Keahlian Teknik Mekanik Otomotiv SMK Swasta 
Pemda Kisaran T.A 2011/2012. Skripsi. Medan: UNIMED

Arikunto,S. (2011). Dasar-Dasar Evaluasi Pendidikan. Jakarta: Bumi Aksara.

Arikunto,S. (2013). Prosedur Penelitian Suatu Pendekatan Praktik. Jakarta: Rineka Cipta

Departemen Pendidikan dan Kebudayaan, (2003). Kamus Besar Bahasa Indonesia. Jakarta: Balai Pustaka.

http://restifaisal.blogspot.com/2013/11/definisiteori-model-metode-strategi.html diakses $\underline{26 \text { juli 2014/13.00) }}$

Huda, Miftahul. (2011). Cooperative learning metode, teknik, struktur dan mode penerapan. Yogyakarta: Pustaka Pelajar.

Rusaman. (2012) Model-Model Pembelajaran. Bandung: PT Raja Grafinda Persada

Sanjaya, W. (2011). Stategi Pembelajaran Berorientasi Standart Proses Pendidikan. Jakarta: Kencana Prenada.
Sardiman, A.M. (2011). Interaksi dan Motivasi Belajar-Mengajar. Jakarta: Rajawali Pers.

Slameto. (2010). Belajar Dan Faktor-Faktor Yang Mempengaruhinya. Jakarta: Rineka Cipta

Surya, Rahmat. (2011). Implementasi Metode Pembelajaran Aktif Tipe Quiz Team Untuk Meningkatkan Hasil Belajar Teknik Digital Di SMK N 2 Langsah. Skripsi. Medan: UNIMED

Sudjana. (2005). Metode Statistika. Bandung: Tarsito

Sugiono. (2012). Metode Penelitian Pendidikan. Bandung: Alfabeta

Suprijono, Agus. (2009). Cooperative Learning Teori dan Aplikasi PAIKEM. Yogyakarta: Pustaka Pelajar

Syaifu Bahri Jamarah. (2011) Psikologi Belajar. Jakarta: Rineka Cipta

Trianto. (2009). Mendesain Model Pembelajaran Inovatif-Progresif.Surabaya: Kencana Prenada Media Group 